\title{
Pengaruh Likuiditas, Profitabilitas, Financial Leverage, dan Arus Kas Operasi Dalam Memprediksi Kondisi Financial Distress
}

\author{
Dita Maretha Rissi ${ }^{1}$, Lisa Amelia Herman ${ }^{2}$ \\ ${ }^{1}$ Jurusan Akuntansi, Politeknik Negeri Padang \\ Email: ditamaretharissi@gmail.com \\ 2Jurusan Akuntansi, Politeknik Negeri Padang \\ Email: $\underline{\text { isa.ameliaherman@gmail.com }}$
}

\begin{abstract}
Financial distress occurs before the bankruptcy of a company. Thus the financial distress model needs to be developed, because by knowing the company's financial distress from an early age, it is hoped that actions can be taken to anticipate conditions that lead to bankruptcy. Financial distress can be measured through financial statements by analyzing financial statements. This study aims to determine and analyze the effect of liquidity, profitability, financial leverage, and operating cash flow in predicting financial distress conditions for manufacturing companies listed on the Indonesia Stock Exchange in 2016-2020. Data from the company's official website and completed from the IDX and ICMD websites. There are independent variables, namely liquidity, profitability, financial leverage, and operating cash flow, while the dependent variable in this study is financial distress. The data analysis method used in this research is logistic regression analysis method which aims to determine the role of each independent variable in influencing the dependent variable. The results of this study indicate that liquidity has no effect on financial distress, meaning that if the company is able to pay its debts well, then it is likely that the company will not experience financial distress. Profitability has no effect on financial distress, meaning that the size of the company's profit value has no effect on the company so that it avoids financial distress conditions. Financial leverage has a positive effect on financial distress, meaning that if the company has higher debt and is not followed by high sales results, it can allow failure to pay debts which causes the company to be in financial distress. Cash flow has no effect on financial distress, meaning that if the company has a good operating cash flow value, it will not experience financial distress.
\end{abstract}

Keywords: Liquidity, profitability, financial leverage, cash flow, financial distress

\begin{abstract}
ABSTRAK
Financial distress terjadi sebelum kebangkrutan pada suatu perusahaan. Dengan demikian model financial distress perlu untuk dikembangkan, karena dengan mengetahui kondisi financial distress perusahaan sejak dini diharapkan dapat dilakukan tindakan-tindakan untuk mengantisipasi kondisi yang mengarah pada kebangkrutan. Financial distress dapat diukur melalui laporan keuangan dengan cara menganalisis laporan keuangan. Penelitian ini merupakan sebuah penelitian kuantitatif yang bertujuan untuk mengetahui dan menganalisis pengaruh likuiditas, profitabilitas, financial leverage, dan arus kas operasi dalam memprediksi kondisi financial distress untuk perusahaan manufaktur yang terdaftar di Bursa Efek Indonesia pada tahun 2016-2020. Dalam penelitian ini, data yang digunakan adalah data sekunder yang diperoleh dari website
\end{abstract}


resmi perusahaan dan dilengkapi dari website BEI dan ICMD. Pada penelitian ini terdapat variabel independen yaitu likuiditas, profitabilitas, financial leverage, dan arus kas operasi, sedangkan variabel dependen pada penelitian ini adalah financial distress. Metode analisis data yang digunakan pada penelitian ini adalah metode analisis regresi logistic yang bertujuan untuk mengetahui peran dari masing-masing variabel independen dalam mempengaruhi variabel dependen. Hasil dari penelitian ini menunjukan likuiditas tidak berpengaruh terhadap kondisi financial distress, artinya apabila perusahaan mampu membayar hutangnya dengan baik, maka kemungkinan besar perusahaan tidak akan mengalami kondisi financial distress. Profitabilitas tidak berpengaruh terhadap kondisi financial distress artinya besar atau kecilnya nilai profit perusahaan tidak memiliki pengaruh terhadap perusahaan sehingga terhindar dari kondisi financial distress. Financial leverage berpengaruh positif terhadap kondisi financial distress artinya jika perusahaan yang memiliki hutang semakin tinggi dan tidak diikuti dengan hasil penjualan yang tinggi maka dapat memungkinkan kegagalan dalam membayar utang yang menyebabkan perusahaan dalam kondisi financial distress. Arus kas tidak berpengaruh terhadap kondisi financial distress artinya apabila perusahaan memiliki nilai arus kas operasional yang baik, maka tidak akan mengalami kondisi financial distress.

Kata Kunci: Likuiditas, profitabilitas, financial leverage, arus kas operasi, financial distress

\section{Pendahuluan}

Kondisi ekonomi yang selalu mengalami perubahan telah mempengaruhi kegiatan dan kinerja perusahaan, baik perusahaan kecil maupun perusahaan besar sehingga banyak perusahaan yang akan mengalami kebangkrutan. Terutama beberapa perusahaan manufaktur yang terdapat di BEI (Bursa Efek Indonesia). Kebangrutan suatu perusahaan dapat dilihat dan diukur melalui laporan keuangannya. Agar informasi laporan keuangan yang tersaji menjadi lebih bermanfaat dalam pengambilan keputusan, maka data keuangan harus dikonversi menjadi informasi yang berguna dalam pengambilan keputusan ekonomis. Untuk membuktikan bahwa laporan keuangan bermanfaat maka perlu dilakukan penelitian. Salah satu bentuk penelitiannya yaitu dengan cara menggunakan rasio-rasio keuangan untuk memprediksi kinerja perusahaan seperti kebangkrutan dan financial distress.

Financial distress terjadi sebelum kebangkrutan pada suatu perusahaan. Dengan demikian model financial distress perlu untuk dikembangkan, karena dengan mengetahui kondisi financial distress perusahaan sejak dini diharapkan dapat dilakukan tindakantindakan untuk mengantisipasi kondisi yang mengarah pada kebangkrutan. Financial distress dapat diukur melalui laporan keuangan dengan cara menganalisis laporan keuangan. Laporan keuangan merupakan hasil dari suatu aktivitas yang bersifat teknik berdasarkan pada metode dan prosedur-prosedur yang memerlukan penjelasanpenjelasan agar tujuan atau maksud untuk menyediakan informasi yang bermanfaat dapat dicapai. Laporan keuangan dapat digunakan sebagai alat untuk membuat proyeksi tentang berbagai aspek finansial perusahaan di masa mendatang.

Berbagai penelitian telah dilakukan untuk mengkaji manfaat yang bisa dipetik dari analisis rasio keuangan. Penelitian yang dilakukan oleh [2] merupakan penelitian awal yang mengkaji pemanfaatan analisis rasio keuangan sebagai alat untuk memprediksi kebangkrutan perusahaan. Model Altman ini dikenal dengan Z-score yaitu, skor yang ditentukan dari hitungan standar kali nisbah-nisbah keuangan yang menunjukan tingkat 
kemungkinan dari hitungan standar kali nisbah-nisbah keuangan yang menunjukan tingkat kemungkinan kebangkrutan perusahaan. Penelitian yang dilakukan oleh [6] menguji manfaat rasio keuangan dalam memprediksi laba satu tahun ke depan, namun tidak bermanfaat untuk memprediksi lebih dari satu tahun. Penelitian juga dilakukan oleh [3] melakukan penelitian terhadap 24 perusahaan yang mengalami finansial distress dan 62 perusahaan yang tidak mengalami financial distress, dengan menggunakan model logit mereka berusaha untuk menentukan rasio keuangan yang paling dominan untuk memprediksi adanya finansial distress. Temuan dari penelitian adalah variabel sales, current assets/current liabilities dan cashflow growth rate memiliki hubungan negative terhadap kemungkinan perusahaan akan mengalami finansial distress dan variabel net fixed asset/total assets, long-term debt/equity dan notes payable/ total assets memiliki hubungan positif terhadap kemungkinan perusahaan akan mengalami finansial distress.

Penelitian ini dilakukan untuk menguji kembali beberapa faktor dalam penelitian terdahulu yang mempengaruhi kondisi finansial distress perusahaan karena dalam penelitian terdahulu yang hasilnya diperoleh ada yang berbeda, seperti dalam penelitian dari [6] menunjukan rasio likuiditas memiliki hubungan negatif terhadap kemungkinan perusahaan akan mengalami financial distress. Sedangkan dalam penelitian [1] menunjukan likuiditas berpengaruh positif terhadap kondisi financial distress perusahaan. Karena semakin besar rasio likuiditas maka semakin kecil perusahaan akan mengalami kondisi financial distress. Variabel profitabilitas juga mempunyai hasil yang berbeda dari penelitian terdahulu, seperti dalam penelitian [3] menunjukan variabel profitabilitas berpengaruh signifikan dalam prediksi financial distress. Karena semakin besar nilai profitabilitas (ROA) maka akan semakin besar kemungkinan perusahaan mengalami financial distress. Fenomena ini adalah fenomena dimana kondisi perekonomian sedang labil. Sebaliknya penelitian [9] profitabilitas berpengaruh signifikan terhadap financial distress perusahaan artinya semakin besar profitabilitas semakin mengurangi kondisi financial distress perusahaan. Kondisi demikian menunjukan kondisi perekonomian sedang stabil.

Dari uraian diatas, maka penelitian ini menarik dilakukan karena melihat kondisi perekonomian di Indonesia yang hampir saja mengalami keterpurukan atau berpotensi krisis yang akan mengakibatkan beberapa perusahaan terkena imbas akan mengalami kebangkrutan seperti yang disampaikan oleh [5]. Sehingga dibutuhkan beberapa startegi yang layak dilakukan bagi beberapa perusahaan untuk mengantisipasi terjadinya kondisi financial distress. Selain itu, penelitian ini menarik dilakukan karena untuk memverifikasi ulang penelitian terdahulu yang dilakukan oleh [4] dengan variabel independen yaitu likuiditas, profitabilitas dan financial leverage dalam memprediksi kondisi financial distress perusahaan. Namun, pada penelitian saat ini dilakukan penambahan variabel independen yaitu, arus kas operasi. Penambahan arus kas operasi sebagai variabel independen diperkuat dengan teori yang dinyatakan oleh [6], yang menyatakan bahwa cash flow from operations (CFFO) atau arus kas operasi dapat memprediksi kebangkrutan perusahaan. Sehingga faktor-faktor yang diuji dalam penelitian ini adalah likuiditas, 


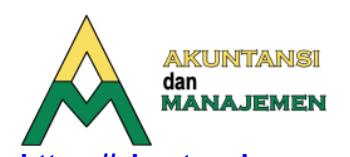

https://akuntansi.pnp.ac.id/jam

e-ISSN 2657-1080, p-ISSN 1858-3687

profitabilitas, financial leverage dan arus kas operasi terhadap kondisi finansial distress perusahaan manufaktur yang terdaftar di BEI.

\section{Landasan Teori \\ Teori Sinyal}

Pemberian sinyal yang didefenisikan sebagai tindakan manajemen puncak yang tidak rasional jika dilakukan oleh manajemen yang lebih rendah. Pemberian sinyal merupakan usaha manajemen yang memiliki informasi kebih ketimbang investor tetapi berusaha untuk menyajikannya pada investor guna meningkatkan keputusan investasi. Sehingga dapat diperoleh kabar baik dan kabar buruk mengenai tindakan manajemen terkait dengan kondisi perusahaan dan keputusan investasi. Teori sinyal berguna untuk menggambarkan perilaku ketika dua pihak (individu dan organisasi) memiliki informasi yang berbeda. Hal ini berarti teori sinyal menekankan kepada pentingnya informasi yang dikeluarkan oleh perusahaan. Informasi tersebut dapat berupa laporan keuangan, informasi kebijakan perusahaan maupun informasi lain yang diungkapkan langsung oleh manajemen perusahaan [10].

\section{Financial Distress}

Financial distress dapat digambarkan dari dua titik ekstrem yaitu kesulitan likuiditas jangka pendek sampai insolvable. Kesulitan keuangan jangka pendek biasanya bersifat jangka pendek, tetapi bias berkembang menjadi parah. Indicator kesulitan keuangan dapat dilihat dari analisis aliran kas, analisis strategi perusahaan, dan laporan keuangan perusahaan [5]. Financial distress merupakan suatu penurunan kinerja (laba), sedangkan mengkategorikan perusahaan dengan financial distress apabila selama dua tahun berturut-turut mengalami laba operasi negatif [2]. Perusahaan yang berada kesulitan keuangan yaitu perusahaan yang memiliki interest coverage ratio (rasio laba usaha terhadap biaya bunga) kurang dari satu. Menurut [6], financial distress merupakan tahap penurunan kondisi keuangan yang terjadi sebelum terjadinya kebangrutan ataupun likuidasi [8]. Kriteria perusahaan yang mengalami financial distress adalah sebagai berikut:

a. Beberapa tahun memperoleh laba bersih negatif

b. Menghentikan pembayaran dividen

c. Mengalami restrukturisasi besar atau penghentian usaha

\section{Kebangkrutan}

Kebangkrutan dapat didefenisikan sebagai suatu keadaan atau situasi dimana perusahaan mengalami kekurangan dan ketidakcukupan dana untuk menjalankan atau melanjutkan usahanya. Dengan kata lain bangkrut juga dapat diartikan sebagai suatu keadaan atau situasi dimana perusahaan gagal atau tidak mampu lagi memenuhi kewajibannya kepada kreditur (melalui tindakan hukum) [5]. 


\section{Laporan keuangan}

Laporan keuangan merupakan bagian dari proses pelaporan keuangan. Laporan keuangan yang lengkap biasanya meliputi neraca, laporan laba rugi, laporan perubahan posisi keuangan (yang dapat disajikan dalam berbagai cara seperti misalnya sebagai laporan arus kas atau laporan arus dana), catatan-catatan dan bagian integral dari laporan keuangan. Berdasarkan definisi laporan keuangan di atas secara garis besar bahwa laporan keuangan merupakan hasil tindakan pembuatan dan peringkasan data keuangan perusahaan yang disusun serta ditafsirkan secara sistematis dan tepat untuk kepentingan internal maupun eksternal perusahaan. Laporan keuangan yang disusun dengan eksistensi suatu perusahaan, pada hakikatnya merupakan alat komunikasi. Disamping sebagai alat komunikasi, laporan keuangan sekaligus sebagai pertanggungjawaban bagi manajemen kepada semua pihak yang menanamkan dan mempercayakan pengelolaan dananya di dalam perusahaan tersebut terutama kepada pemilik.

\section{Analisis Laporan Keuangan}

Empat hal yang mendorong analisis laporan keuangan dilakukan dengan model rasio keuangan yaitu [6]:

a. Untuk mengendalikan pengaruh perbedaan besaran antar perusahaan atau antar waktu.

b. Untuk membuat data menjadi lebih memenuhi asumsi alat statistic yang digunakan.

c. Untuk menginvestasikan teori yang terkait dengan rasio keuangan.

d. Untuk mengkaji hubungan empiris antara rasio keuangan dan estimasi atau prediksi variabel tertentu (seperti kebangrutan atau financial distress).

\section{Rasio Keuangan Sebagai Alat untuk Memprediksi Financial Distress}

Pengertian rasio keuangan merupakan indeks yang menghubungkan dua angka akuntansi dan diperoleh dengan membagi satu angka dengan angka lainnya. Rasio keuangan digunakan untuk mengevaluasi kondisi keuangan dan kinerja perusahaan.

a. Likuiditas

Likuiditas merupakan suatu indicator mengenai kemampuan perusahaan untuk membayar semua kewajiban finansial jangka pendek pada saat jatuh tempo dengan aktiva lancar yang tersedia dan ketidakmampuan perusahaan untuk memenuhi kewajiban lancarnya merupakan suatu masalah likuiditas yang ekstrem, masalah ini dapat mengarah pada penjualan investasi dan asset lainnya yang dipaksakan dan bahkan mengarah pada kesulitan insolvabilitas dan kebangkrutan [9]. Rasio ini dihitung dengan rumus sebagai berikut:

Current Rasio $=$ Asset Lancar $/$ Kewajiban Lancar 
b. Profitabilitas

Profitabilitas adalah rasio yang mengukur seberapa besar efektivitas manajemen atau eksekutif perusahaan yang dibuktikan dengan kemampuan menciptakan keuntungan. Profitabilitas menunjukan efisiensi dan efektivitas penggunaan asset perusahaan karena rasio ini mengukur kemampuan perusahaan menghasilkan laba berdasarkan penggunaan asset. Dengan adanya efektivitas dari penggunaan asset perusahaan maka akan mengurangi biaya yang dikeluarkan oleh perusahaan, maka perusahaan akan memperoleh penghematan dan akan memiliki kecukupan dana untuk menjalankan usahanya. Dengan adanya kecukupan dana tersebut maka kemungkinan perusahaan mengalami financial distress akan menjadi lebih kecil [11]. ROA dapat dihitung dengan rumus berikut:

ROA = Laba Bersih / Total Aktiva

c. Financial Leverage

Rasio leverage merupakan rasio yang digunakan untuk mengukur sejauhmana aktiva perusahaan dibiayai oleh hutang. Leverage menekankan pada peran penting pendanaan utang bagi perusahaan dengan menunjukan persentase aktiva perusahaan yang didukung oleh pendanaan utang. Semakin besar jumlah utang maka semakin besar potensi perusahaan mengalami kesulitan keuangan dan kebangrutan. Kebangrutan biasanya terjadi dengan diawali dengan adanya moment gagal bayar, hal ini disebabkan semakin besar jumlah hutang, semakin tinggi probabilitas finansial distress. Perusahaan dengan banyak kreditor akan akan semakin cepat bergerak ke arah financial distress, dibanding perusahaan dengan kreditor tunggal [10]. Rumus financial leverage adalah sebagai berikut:

Debt Ratio $=$ Total Utang $/$ Total Aktiva

d. Arus Kas Operasi

Aktivitas perusahaan yang berkaitan dengan pengeluaran kas seperti pembelanjaan perusahaan, pembelian aktiva tetap, pembiayaan ekspansi perusahaan serta pengeluaran kas lainnya dan yang berkaitan dengan penerimaan kas dari penjualan dan pendapatanlainnya tidak dapat dijelaskan melalui neraca dan laporan laba rugi, melainkan dalam laporan arus kas. Laporan arus kas melaporkan penerimaan kas, pengeluaran kas dan perubahan bersih kas, baik yang berasal dari aktivitas operasi, investasi mapun pendanaan.

Adapun formula yang digunakan dalam menghitung rasio arus kas operasi adalah dengan membagi arus kas bersih operasi dengan kewajiban lancar perusahaan.

Arus kas operasi / kewajiban lancar = arus kas bersih operasi / kewajiban lancar [10]. 


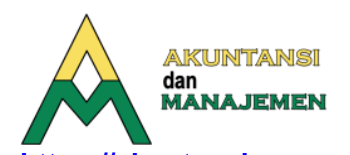

https://akuntansi.pnp.ac.id/jam

e-ISSN 2657-1080, p-ISSN 1858-3687

\section{Kerangka Berpikir}

Kerangka berpikir penelitian ini dapat digambarkan sebagai berikut:

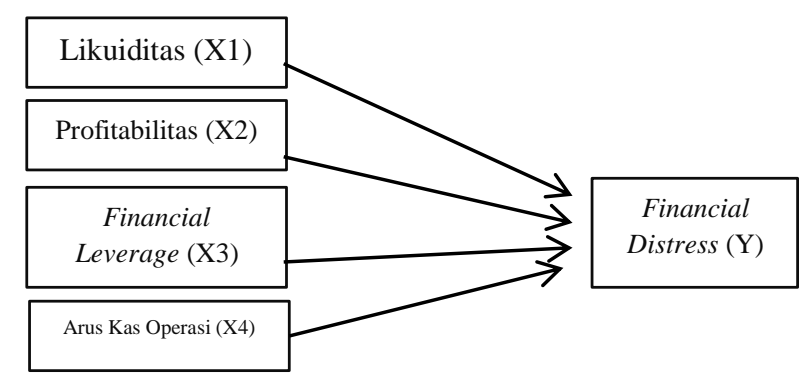

\section{Gambar 1: Kerangka Berpikir}

\section{Pengembangan Hipotesis}

Hipotesis penelitian yang diajukan adalah sebagai berikut:

Rasio likuiditas adalah rasio-rasio yang dimaksudkan untuk mengukur likuiditas perusahaan. Likuiditas perusahaan menunjukan kemampuan perusahaan mendanai operasional perusahaan dalam memenuhi kewajiban (utang) jangka pendek. Likuiditas perusahaan diasumsikan dalam penelitian ini mampu menjadi alat prediksi kondisi financial distress suatu perusahaan dan diukur dengan current ratio, yaitu aktiva lancar dibagi hutang lancar (CA/CL). Current ratio mengukur kemampuan perusahaan memenuhi utang jangka pendeknya dengan menggunakan aktiva lancarnya. Semakin besar rasio likuiditas maka semakin kecil kemungkinan perusahaan mengalami financial distress [6].

H1: Likuiditas berpengaruh terhadap kondisi financial distress perusahaan.

Profitabilitas merupakan hasil akhir bersih dari berbagai kebijakan dan keputusan, dimana rasio ini digunakan sebagai alat pengukur atas kemampuan perusahaan untuk memperoleh keuntungan dari setiap rupiah penjualan yang dihasilkan. Profitabilitas adalah tingkat keberhasilan atau kegagalan perusahaan selama jangka waktu tertentu.

Perusahaan yang memiliki profitabilitas tinggi berarti memiliki laba yang besar. Hal ini berarti perusahaan tersebut semakin kecil kemungkinan untuk mengalami financial distress. Profitabilitas berpengaruh negative dan signifikan terhadap kondisi financial distress perusahaan artinya semakin besar profitabilitas suatu perusahaan, semakin mengurangi kondisi financial distress perusahaan tersebut dan rasio yang paling dominan dalam memprediksi kondisi financial distress adalah rasio profitabilitas [4]. Berdasarkan uraian diatas maka hipotesis kedua dalam penelitian ini adalah sebagai berikut:

H2: Profitabilitas berpengaruh terhadap kondisi financial distress perusahaan. 
Financial leverage menunjukan kemampuan perusahaan untuk memenuhi kewajiban baik untuk jangka pendek maupun jangka panjang. Analisis terhadap rasio ini diperlukan untuk mengukur kemampuan perusahaan dalam membayar utang (jangka pendek dan jangka panjang) apabila suatu saat perusahaan dilikuidasi atau dibubarkan. Penelitian yang dilakikan oleh [5] menggunakan indicator yang digunakan untuk mengukur tingkat financial leverage perusahaan dalam penelitian ini adalah total utang dibagi total modal (Debt to Equity Ratio).

Suatu perusahaan yang memiliki leverage keuangan yang tinggi berarti memiliki banyak utang pada pihak luar. Ini berarti perusahaan tersebut memiliki rasio keuangan yang tinggi karena mengalami kesulitan keuangan (financial distress) [4], risiko keuangan yang tinggi mengindikasikan bahwa perusahaan mengalami kesulitan keuangan (financial distress). Kesulitan keuangan merupakan berita buruk yang akan mempengaruhi kondisi perusahaan di masyarakat. menggunakan model logit dan probit dalam memprediksi kondisi financial distress perusahaan dengan menggunakan sampel 64 perusahaan yang dikategorikan sehat dan 64 perusahaan yang dikategorikan distress sepanjang periode 1990-1996. Hasil mengindikasikan efisiensi model ini dua tahun sebelum krisis, dan dalam penelitian ini rasio leverage merupakan rasio yang dapat digunakan untuk memprediksi kondisi financial distress perusahaan. Karena semakin besar rasio ini akan semakin kecil kemungkinan perusahaan mengalami financial distress.

Penelitian yang dilakukan oleh [8] bertujuan untuk membuktikan manfaat laporan keuangan dalam memprediksi kinerja perusahaan seperti financial distress, penelitian ini membuat 12 persamaan regresi untuk menunjukan bahwa rasio keuangan dapat digunakan untuk memprediksi financial distress. Hasil penelitian ini menunjukan bahwa rasio-rasio keuangan disebutkan bahwa rasio financial leverage yaitu variabel total utang dibagi dengan total model (DER) dapat digunakan untuk memprediksi financial distress suatu perusahaan. Karena semakin besar rasio financial leverage akan semakin besar kemungkinan perusahaan mengalami financial distress. Koefisien dalam variabel ini bertanda positif, artinya variabel DER memiliki pengaruh positif terhadap financial distress suatu perusahaan. Hipotesis yang ketiga dalam penelitian ini adalah sebagai berikut:

H3: Financial Leverage berpengaruh terhadap kondisi financial distress perusahaan.

Laporan arus kas merupakan campuran antara laporan laba-rugi dengan laporan posisi keuangan. Laporan arus kas dapat mengekspresikan laba bersih perusahaan yang berkaitan dengan nilai perusahaan sehingga jika arus kas meningkat, maka laba perusahaan akan meningkat dan hal ini akan meningkatkan nilai perusahaan dan selanjutnya juga akan menaikan laba perusahaan. Suatu perusahaan memiliki arus kas operasi yang tinggi berarti memiliki sumber dana untuk melakukan aktivitas operasinya seperti untuk melunasi pinjaman, memelihara kemampuan operasi perusahaan, membayar deviden dan melakukan investasi baru tanpa mengandalkan sumber pendanaan dari luar. Rasio arus kas bersih meningkat, maka laba perusahaan akan meningkat dan hal ini akan meningkatkan nilai perusahaan dan selanjutnya juga akan 
menaikkan laba perusahaan sehingga perusahaan tidak akan mengalami financial distress. Cash flow from operating merupakan salah satu factor yang dapat digunakan dalam memprediksi financial distress suatu perusahaan. Rasio keuangan yang berasal dari laporan arus kas menunjukan bahwa rasio arus kas bersih dari aktivitas operasi dibagi dengan total aktiva dan rasio arus kas bersih dari aktivitas operasi dibagi dengan hutang lancar dapat digunakan untuk memprediksi kondisi financial distress perusahaan. Dalam penelitian ini arus kas operasi (AKO) mampu menjadi alat prediksi kondisi financial distress suatu perusahaan [3].

Hipotesis keempat yang dikembangkan berdasarkan uraian diatas adalah sebagai berikut: H4: Arus kas berpengaruh terhadap kondisi financial distress perusahaan.

\section{Metodologi Penelitian \\ Jenis Penelitian}

Berdasarkan rumusan masalah dan tujuan penelitian yang telah diuraikan di atas, maka penelitian ini tergolong penelitian kausatif (causative). Kausatif merupakan penelitian dengan menggunakan karakteristik masalah berupa hubungan sebab akibat antara dua variabel atau lebih. Penelitian ini menguji hubungan antara variabel independen (X) dengan variabel dependen (Y). Dimana penelitian ini bertujuan untuk melihat seberapa besar variabel independen mempengaruhi variabel dependen. Penelitian ini berusaha menjelaskan pengaruh profitabilitas (X1), likuiditas (X2), financial leverage (X3) dan arus kas operasi (X4) sebagai variabel independen dalam memprediksi financial distress (Y) pada perusahaan manufaktur yang terdaftar di BEI sebagai variabel dependen.

\section{Jenis Data Menurut Waktu Pengumpulan}

Data yang digunakan yaitu data panel, yaitu data yang menggabungkan antara data runtun waktu (time series) dan data silang (cross section). Karena itu, data dari penelitian ini akan memiliki beberapa objek dan beberapa periode waktu. Dimana data yang digunakan dalam penelitian ini adalah data Laporan Keuangan Perusahaan Manufaktur dari tahun 2016-2020.

\section{Sumber Data}

Berdasarkan sumber datanya, data yang digunakan dalam penelitian ini adalah data sekunder, yaitu data yang diperoleh dari sumber yang tidak langsung memberikan kepada pengumpul data [11]. Dalam penelitian ini data diperoleh dari website resmi perusahaan dan dilengkapi dari website BEI dan ICMD. Data sekunder yang digunakan dalam penelitian ini adalah data laporan keuangan dan profil perusahaan-perusahaan manufaktur yang terdaftar di BEI tahun 2016-2020. 


\section{Definisi Operasional Variabel dan Pengukuran}

Adapun definisi opersional variabel dan pengukuran pada penelitian ini adalah sebagai berikut:

\section{Variabel Dependen (Y)}

Variabel dependen yaitu variabel dimana faktor keberadaannya dipengaruhi oleh variabel independen [11]. Variabel dependen yang digunakan dalam penelitian ini adalah kondisi financial distress perusahaan yang menggunakan variabel dummy. Variabel dummy adalah variabel yang digunakan untuk mengkuantitatifkan variabel yang bersifat kualitatif. Variabel dummy merupakan variabel yang bersifat kategorikal yang diduga mempunyai pengaruh terhadap variabel yang bersifat kontiniu. Dalam penelitian ini penentuan financial distress perusahaan dikatakan mengalami financial distress jika selama dua tahun berturut-turut mengalami laba bersih operasi (net operating income) negative, sedangkan perusahaan yang tidak mengalami laba bersih (net operating income) negative selama dua tahun berturut-turut tidak dikategorikan mengalami financial distress. Adapun pengukuran yang digunakan dalam penelitian ini merujuk kepada penelitian yang sebelumnya dilakukan oleh [3] adalah sebagai berikut:

$$
\begin{array}{ll}
1 \text { (satu }) & =\text { Financial distress } \\
(\text { nol }) & =\text { Non financial distress }
\end{array}
$$

\section{Variabel Independen (X)}

Variabel independen merupakan tipe variabel yang menjelaskan, mempengaruhi atau menjadi penyebab berubahnya variabel dependen [10]. Variabel independen dalam penelitian ini adalah sebagai berikut:

a. Likuiditas (X1)

Rasio likuiditas merupakan rasio yang menggambarkan kemampuan perusahaan dalam memenuhi kewajiban (utang) jangka pendek. Likuiditas dalam penelitian ini menggunakan rasio lancar (current ratio) dengan rumus:

$$
\text { Current Ratio = Aktiva / Kewajiban Lancar }
$$

b. Profitabilitas (X2)

Rasio profitabilitas merupakan rasio untuk menilai kemampuan perusahaan dalam mencari keuntungan. Rasio ini juga memberikan ukuran tingkat efektivitas manajemen suatu perusahaan [6]. Profitabilitas dalam penelitian ini menggunakan ROA (Return on Asset) dengan rumus:

$$
\text { ROA = Laba Bersih / Total Aktiva }
$$

\section{c. Financial Leverage (X3)}

Financial leverage menunjukan kemampuan perusahaan untuk memenuhi kewajiban baik untuk jangka pendek maupun jangka panjang. Analisis terhadap rasio ini diperlukan untuk mengukur kemampuan perusahaan dalam membayar utang (jangka pendek dan jangka panjang) apabila pada suatu perusahaan dilikuidasi atau dibubarkan. Financial leverage di proxikan dengan DER yang merupakan perbandingan 
antara total utang dibagi dengan modal [6]. DER dalam penelitian ini dirumuskan sebagai berikut:

$$
\text { DER }=\text { Total Utang / Total Modal }
$$

d. Arus Kas Operasi (X4)

Arus kas dari aktivitas operasi ini merupakan aktivitas yang mendukung produktivitas dan mengganti kerugian investor. Arus kas dari aktivitas operasi ini cukup untuk menggantikan sumber daya perusahaan yang sudah using, memberikan kewajiban kepada kreditor, dan memberikan kompensasi kepada pemilik atas investasi mereka. Sehingga arus kas aktivitas operasi dapat menjadi sinyal bagi investor mengenai kondisi perusahaan. Ada variabel yang dapat digunakan untuk memprediksi kebangkrutan yaitu cash flow from operating (CFFO), utang jangka pendek (current assets/CL) [3]. Maka rasio yang signifikan adalah CFFO/CL. Dalam penelitian ini arus kas operasi dapat dirumuskan sebagai berikut:

Arus Kas Operasi dari aktivitas operasi $(\mathrm{CFFO} / \mathrm{CL})=$ Arus kas bersih operasi / Kewajiban Lancar

\section{Populasi dan Sample}

Populasi penelitian ini adalah seluruh perusahaan manufaktur yang terdaftar di Bursa Efek Indonesia periode 2016-2020. Laporan tahunan periode tersebut dipilih karena dianggap dapat mewakili kondisi perekonomian yang stabil.

Teknik pengambilan sample yang digunakan dalam penelitian ini adalah metode purposive sampling, yaitu penentuan sampel berdasarkan kriteria tertentu sesuai dengan yang dikehendaki oleh peneliti. Adapun kriteria-kriteria yang dipilih dalam penentuan sample adalah sebagai berikut:

a. Perusahaan manufaktur yang terdaftar di Bursa Efek Indonesia (BEI) sejak tahun 2016-2020 secara terus-menerus.

b. Perusahaan menerbitkan laporan keuangan 31 Desember secara rutin selama 5 tahun sesuai dengan periode penelitian yang diperlukan untuk periode 2016, 2017, 2018, 2019, dan 2020 (laporan keuangan per 31 Desember merupakan laporan keuangan yang telah diaudit).

c. Perusahaan tidak melakukan merger dan akuisisi.

d. Perusahaan mempunyai laba bersih (net income) negatif selama dua tahun atau secara berturut-turut. Kriteria ini menunjukan kondisi financial distress karena dengan adanya laba bersih (net income) negatif selama dua tahun atau secara berturut-turut berarti perusahaan mengalami penurunan kondisi keuangan atau kerugian.

e. Perusahaan yang dipakai sebagai validasi model adalah perusahaan yang cenderung tidak mengalami financial distress (ditandai dengan tidak terjadinya laba bersih (net income) negatif selama dua tahun atau lebih secara berturut-turut. 


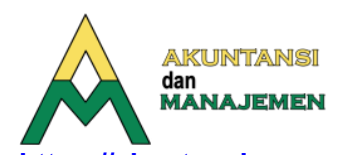

https://akuntansi.pnp.ac.id/jam

e-ISSN 2657-1080, p-ISSN 1858-3687

\section{Metode Pengumpulan Data}

Data yang digunakan dalam penelitian ini adalah data kuantitatif, yaitu data dalam bentuk angka-angka atau data kualitatif yang diangkakan [11]. Data kuantitatif dalam penelitian ini adalah laporan keuangan dan ringkasan kinerja perusahaan manufaktur yang terdaftar di BEI tahun 2016-2020.

Metode pengumpulan data yang digunakan dalam penelitian ini adalah metode observasi dengan teknik observasi non partisipan, yaitu dengan cara membaca, mengamati, mencatat serta mempelajari uraian buku-buku, jurnal akuntansi dan bisnis, ICMD serta mengunduh data dan informasi dari situs resmi perusahaan.

\section{Metode Analisis Data}

Metode analisis data dalam penelitian ini adalah menggunakan bantuan program komputer yaitu program SPSS 22. Adapun yang dilakukan adalah sebagai berikut:

\section{Model Analisis Regresi Logistik}

Analisis regresi logistic digunakan untuk menguji apakah variabel likuiditas, profitabilitas, financial leverage, dan arus kas berpengaruh dalam kondisi financial distress. Teknik analisis regresi yang digunakan dalam penelitian ini adalah analisis logistic binner yang variabel dependennya berupa variabel kategorik. Dimana model regresi dinyatakan sebagai berikut [11]:

$$
\mathrm{P}=\left\{1+\operatorname{Exp}-\left(B_{0}+B_{1} L i q+B_{2} \text { PROFIT }+B_{3} \text { Finlev }+ \text { Arkas }\right)\right\}
$$

Dimana:

$\mathrm{P}$

$B_{0}$

Liq

PROFIT

Finlev

Arkas

$B_{1-4}$

$\operatorname{Exp}$
= Probabilitas perusahaan mengalami financial distress

= Konstanta

= Likuiditas

$=$ Profitabilitas

= Leverage

= Arus Kas Operasi

= Koefisien Regresi

= Kesalahan yang mempunyai nilai pengharapan sebesar nol

\section{Langkah-Langkah Analisis}

a. Menilai kelayakan model regresi: nilai goodnest of test yang diukur dengan nilai chisquare pada bagian bawah uji hosmer dan lemeshow harus menunjukan angka probabilitas $>0,05$, artinya tidak ada perbedaan yang nyata antara klasifikasi yang diprediksi dengan klasifikasi yang diamati. Hal ini berarti model regresi logistic layak dipakai untuk analisis selanjutnya.

b. Menilai keseluruhan model (overall fit): dari angka -2 log likehood, dimana pada awal (block number $=0$ ) angka -2 log likehood harus turun pada block number $=1$. 
Penurunan ini dimana likehood pada regresi logistic menunjukan model regresi yang lebih baik.

c. Uji hipotesis, uji ini bertujuan untuk menguji pengaruh secara parsial antara variabel independen terhadap variabel dependen dengan mengasumsikan variabel lain adalah konstan. Hal ini diperoleh dengan rumus:

$$
t=\beta n / S \beta n
$$

Keterangan :

$\beta \mathrm{n}$ : Koefisien regresi masing-masing variabel

$\mathrm{S} \beta \mathrm{n}$ : Standar error dari masing-masing variabel

Hasil pengujian terhadap t-statistik dengan standar signifikansi $\alpha=5 \%$ adalah:

- Jika sig. < $\alpha$ Hal ini berarti bahwa ada pengaruh secara parsial antara variabel independen terhadap variabel dependen.

- Jika sig. $\geq \alpha$, Ini berarti bahwa tidak ada pengaruh bahwa secara parsial antara variabel independen dengan variabel dependen.

\section{Hasil Penelitian Dan Pembahasan}

\section{Deskripsi Data}

Deskripsi data memberikan gambaran atau deskripsi dan menyajikan data dari suatu variabel yang diteliti pada penelitian kuantitatif untuk menggambarkan data dalam penelitian yang dilihat dari rata-rata, standar deviasi, varian, maksimum, minimum, sum, range, dan kurtosis. Deskripsi data yang dilakukan terdiri dari variabel independen yaitu likuiditas, profitabilitas, financial leverage, dan arus kas serta variabel dependen adalah financial distress. Statistic deskriptif disajikan dari tabel tersebut dapat diinterprestasikan sebagai berikut:

Tabel 1. Hasil Uji Statistik Deskriptif

\begin{tabular}{|c|c|c|c|c|c|c|}
\hline & & $\mathrm{N}$ & Minimum & Maximum & Mean & Std.Deviation \\
\hline LIQ & & 70 & .2 & 70.2 & 14.231 & 8.9028 \\
\hline PROFIT & & 70 & -.0934 & .4004 & -.00893 & .0518016 \\
\hline FINLEV & & 70 & .0456 & .7540 & -.65864 & .2440670 \\
\hline ARKAS & & 70 & -.3405 & .0704 & -.009893 & .0515337 \\
\hline $\begin{array}{l}\text { Valid } \\
\text { (listwise) }\end{array}$ & $N$ & 70 & & & & \\
\hline
\end{tabular}

Sumber: Data Sekunder, diolah 2021

Berdasarkan data tabel diatas dapat diketahui jumlah data yang diteliti sebanyak 70 data. Data tersebut terdari dari 14 perusahaan dan periode pengamatan selama lima tahun yaitu mulai dari tahun 2016-2020.

\section{Analisis Regresi Logistik}

Analisis regresi logitik dilakukan untuk mengetahui besarnya pengaruh variabel independen terhadap variabel dependen. Besarnya variabel independen terhadap 


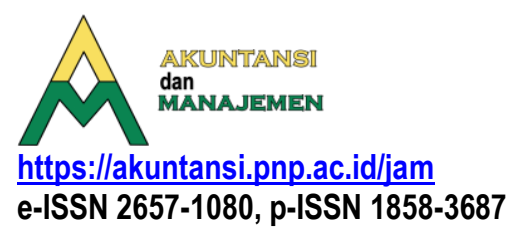

variabel dependen secara bersama-sama dapat dihitung melalui satu persamaan regresi logistic. Dibawah ini merupakan hasil dari analisis regresi logistic yang disajikan pada tabel dibawah ini:

\section{Tabel 2. Hasil Analisis Regresi Logistik}

\begin{tabular}{llrrrrrr}
\hline & & \multicolumn{1}{c}{ B } & \multicolumn{1}{c}{ S.E } & \multicolumn{1}{c}{ Wald } & df & \multicolumn{1}{c}{ Sig. } & \multicolumn{1}{c}{$\operatorname{Exp}(B)$} \\
\hline & LIQ & -.305 & .226 & 1.829 & 1 & .176 & .737 \\
& PROFIT & -6.184 & 9.184 & .453 & 1 & .501 & .002 \\
Step & FINLEV & 9.251 & 3.553 & 6.781 & 1 & .009 & 10.418 .296 \\
$1^{\mathrm{a}}$ - & ARKAS & 20.565 & 10.630 & 3.742 & 1 & .053 & 853.205 .560 .117 \\
& Constant & -.413 & 1.243 & .111 & 1 & .740 & .661 \\
\hline
\end{tabular}

Sumber: Data Sekunder, diolah 2021

Analisis regresi logistic digunakan untuk menguji apakah variabel likuiditas, profitabilitas, financial leverage, dan arus kas berpengaruh terhadap kondisi financial distress. Teknik analisis regresi yang digunakan dalam penelitian ini yaitu analisis regresi logistic biner yang variabel dependennya berupa variabel kategorik. Berdasarkan tabel diatas, maka dapat diperoleh persamaan regresi sebagai berikut:

$$
P=-0.413-0.305 \text { Liq }-6.184 \text { Profit }+9.251 \text { Finlev }+20.565 \text { Arkas }
$$

Regresi logistic ini digunakan untuk menguji apakah probabilitas variabel terikat dapat diprediksi dengan variabel bebasnya. Pengujian likuiditas, profitabilitas, financial leverage, dan arus kas terhadap kondisi finansial distress yaitu dengan menggunakan analisis regresi logistic. Apabila data yang disiapkan telah lolos uji, maka data tersebut dapat diolah dengan menggunakan analisis regresi logistic dan melihat tabel klasifikasi kemudian menguji secara parsial dengan uji wald apakah setiap variabel independen berpengaruh terhadap variabel dependen dan langkah terakhir melakukan uji simultan dengan uji model yang bertujuan untuk mengetahui apakah variabel independen berpengaruh terhadap variabel dependen.

\section{Menilai Kelayakan Model Regresi}

Pada model regresi ini digunakan untuk menilai apakah model regresi tersebut telah dihipotesiskan fit atau tidak dengan data. Pengujian ini dilakukan dengan menggunakan Hormer dan Lemeshow's Goodnesof Fit Test untuk menguji hipotesis nol apakah data cocok atau sesuai dengan model. Dasar pengambilan keputusan yang digunakan adalah sebagai berikut:

a. Jika uji Hormer dan Lemeshow's $<0.05$ artinya hipotesis nol ditolak.

b. Jika uji Hormer dan Lemeshow's $>0.05$ artinya hipotesis nol diterima. 
Pengujian kelayakan model regresi ditunjukan pada tabel dibawah ini:

Tabel 3. Hasil Pengujian Kelayakan Model Regresi

\begin{tabular}{cccc}
\hline & Chi-square & Df & Sig. \\
\hline Step 1 & 16.146 & 8 & .056 \\
\hline
\end{tabular}

Sumber: Data Sekunder, diolah 2021

Berdasarkan tabel diatas menunjukan bahwa nilai statistic Hormer dan Lemeshow's adalah 16.146 dengan nilai probabilitas signifikan sebesar 0.056 yang artinya nilai tersebut diatas 0.05. Dapat disimpulkan bahwa hipotesisi nol diterima. Sehingga model dikatakan fit dan mampu memprediksi nilai observasinya.

\section{Menilai Keseluruhan Model}

Pengujian ini bertujuan untuk menguji kesesuaian antara model dengan data untuk menilai keseluruhan model dengan cara membandingkan antara -2 log likehood pada awal dengan nilai -2 log likehood pada akhir. Dengan menunjukan adanya pengurangan nilai antara -2 log likehood awal dengan nilai -2 log likehood, kemudian untuk selanjutnya -2 log likehood akhir menunjukan bahwa model yang dihipotesiskan fit dengan data.

Tabel 4. Hasil Pengujian Overall Model Fit

\begin{tabular}{cccc}
\hline \multirow{2}{*}{ Iteration } & -2 Log likehood & Coefficients \\
\cline { 3 - 3 } & & & Constant \\
\hline \multirow{2}{*}{ Step 0 } & 1 & 51.898 & .603 \\
& 2 & 51.898 & .620 \\
& 3 & 51.898 & .620 \\
\hline
\end{tabular}

Sumber: Data Sekunder, diolah 2021

Tabel 5. Model Summary

\begin{tabular}{|c|c|c|}
\hline -2 Log likehood & $\begin{array}{l}\text { Cox \& Snell R } \\
\text { Square }\end{array}$ & $\begin{array}{c}\text { Nagelkerke } R \\
\text { Square }\end{array}$ \\
\hline
\end{tabular}

\begin{tabular}{llll}
\hline Step 1 & $18.987 \underline{\text { a }}$ & .578 & .798 \\
\hline
\end{tabular}

Sumber: Data Sekunder, diolah 2021

Berdasarkan tabel diatas dapat diketahui bahwa nilai -2Log likehood awal adalah 51.898 kemudian setelah dimasukkan tiga variabel independen nilai -2Log Likehood akhir mengalami penurunan sebesar 18.987. Penurunan ini menunjukan model regresi yang baik atau bisa juga dikatakan model yang dihipotesiskan Fit dengan data. 


\section{Pengujian Hipotesis (Uji Model)}

Pengujian ini bertujuan untuk menguji tingkat signifikansi variabel bebas secara keseluruhan terhadap variabel terikat. Pengujian ini dapat dikatakan pada tabel Omnibus Test of Model Coefficient dengan melihat nilai Chi-Square pada tabel dibawah ini:

Tabel 6. Omnibus Test of Model Coefficients

\begin{tabular}{lcccc}
\hline & & -Chi-Square & Df & Sig. \\
\hline \multirow{4}{*}{ Step 1 } & Step & 33.090 & 4 & .000 \\
& Block & 33.090 & 4 & .000 \\
& Model & 33.090 & 4 & .000 \\
\hline
\end{tabular}

Sumber: Data Sekunder, diolah 2021

Berdasarkan tabel diatas diketahui nilai Omnibus Test of Model Coefficients adalah sebesar 33.090 dengan tingkat signifikan sebesar 0.000. Tingkat signifikan 0.000 lebih kecil daripada 0.05 yang berarti bahwa variabel likuiditas, profitabilitas, financial leverage, dan arus kas berpengaruh secara bersama-sama terhadap kondisi financial distress.

\section{Uji Wald}

Uji Wald bertujuan untuk mengetahui tingkat signifikansi pada setiap variabel independen terhadap variabel dependen dengan melihat kolom sig yaitu level of significance 5\%. Hasil uji Wald dapat dilhat pada tabel dibawah ini:

Tabel 7. Hasil Uji Wald

\begin{tabular}{|c|c|c|c|c|c|c|c|}
\hline & & B & S.E & Wald & $\mathrm{df}$ & Sig. & $\operatorname{Exp}(B)$ \\
\hline \multirow{5}{*}{$\begin{array}{l}\text { Step } \\
1^{\underline{a}}\end{array}$} & LIQ & -.305 & .226 & 1.829 & 1 & .176 & .737 \\
\hline & PROFIT & -6.184 & 9.184 & .453 & 1 & .501 & .002 \\
\hline & FINLEV & 9.251 & 3.553 & 6.781 & 1 & .009 & 10.418 .296 \\
\hline & ARKAS & 20.565 & 10.630 & 3.742 & 1 & .053 & 853.205 .560 .117 \\
\hline & Constant & -.413 & 1.243 & .111 & 1 & .740 & .661 \\
\hline
\end{tabular}

Sumber: Data Sekunder, diolah 2021

Berdasarkan hasil tabel diatas menunjukan nilai signifikan pada masing-masing variabel berdasarkan prosedur penelitian yang disudah dilakukan. Variabel likuiditas diperoleh nilai wald dengan tingkat signifikan sebesar 0.176 yang berarti bahwa nilai signifikan lebih besar dari 0.05. variabel profitabilitas 0.501 yang berarti bahwa nilai ini lebih besar dari 0.05. variabel financial leverage sebesar 0.009 yang artinya bahwa lebih kecil dari 0.05. Sedangkan variabel arus kas sebesar 0.740 yang artinya adalah lebih besar dari 0.05. 


\section{Pembahasan}

\section{Pengaruh Likuiditas Terhadap Financial Distress}

Variabel likuiditas dalam penelitian ini menunjukan nilai signifikan sebesar 0.176 lebih besar dari 0.05, sehingga dapat disimpulkan bahwa hipotesis H1 ditolak karena variabel likuiditas tidak berpengaruh terhadap kondisi financial distress. Hasil penelitian ini mendukung penelitian yang dilakukan oleh [1] yang menyatakan bahwa likuiditas yang diukur dengan menggunakan current ratio tidak berpengaruh terhadap financial distress. Tidak pengaruhnya likuiditas dikarenakan perusahaan mampu membayar hutangnya dengan baik, maka kemungkinan besar perusahaan tidak akan mengalami kondisi financial distress. Sesuai dengan teori sinyal menjelaskan bagaimana suatu entitas dapat memberikan sinyal baik terhadap pengguna laporan keuangan. Likuiditas yang bagus akan mengirimkan sinyal positif terhadap pihak eksternal melalui laporan keuangan yang diterbitkan.

\section{Pengaruh Profitabilitas Terhadap Financial Distress}

Hasil dari penelitian variabel Profitabilitas menghasilkan nilai signifikan sebesar 0.501 lebih besar dari 0.05, sehingga dapat disimpulkan bahwa hipotesis H2 ditolak. Dengan demikian profitabiltas tidak berpengaruh terhadap financial distress. Tidak berpengaruhnya profitabilitas dikarenakan besar kecilnya profit tidak memiliki pengaruh terhadap perusahaan memiliki modal yang tinggi untuk menutupi pendanaan atau hutang yang besar. Oleh karena itu, perusahaan akan memperoleh penghematan dan memiliki kecukupan dana untuk menjalankan usahanya sehingga terhindar dari financial distress. Sesuai dengan teori sinyal, dimana perusahaan diharapkan selalu memberikan sinyal atas kondisi perusahaan, rasio profitabilitas yang baik dapat menjadi sinyal positif bagi para pihak eksternal yang memiliki kepentingan dengan perusahaan. Hasil penelitian ini sejalan dengan penelitian yang dilakukan oleh [2] yang menyatakan bahwa profitabilitas tidak berpengaruh terhadap financial distress.

\section{Pengaruh Financial Leverage Terhadap Financial Distress}

Variabel financial leverage dalam penelitian ini menghasilkan nilai signifikan sebesar 0.009 lebih kecil dari 0.05, sehingga dapat disimpulkan bahwa hipotesis H3 yaotu financial leverage diterima dengan demikian financial leverage berpengaruh positif dan signifikan terhadap kondisi financial distress. Berdasarkan penelitian ini bahwa perusahaan yang memiliki hutang semakin tinggi jika tidak diikuti dengan hasil penjualan yang tinggi dan stabil, maka dapat memungkinkan terjadinya kegagalan dalam membayar hutang yang dapat menyebabkan kesulitan keuangan bagi perusahaan. Sesuai dengan teori sinyal dijelaskan bahwa dalam sinyal tersebut dapat memberikan informasi yang menyatakan perusahaan sedang dalam kondisi tidak baik. Artinya semakin besar pendanaan perusahaan yang berasal dari hutang, maka akan semakin besar pula kewajiban perusahaan untuk melunasi hutang tersebut. 


\section{Pengaruh Arus Kas Terhadap Financial Distress}

Hasil penelitian ini menunjukan variabel arus kas memiliki nilai signifikan 0.053 lebih besar dari 0.05 sehingga dapat disimpulkan bahwa hipotesis H4 ditolak dengan demikian arus kas tidak berpengaruh terhadap kondisi financial distress. Hasil penelitian ini mendukung penelitian yang dilakukan oleh [3] menyatakan bahwa arus kas dari kegiatan operasi tidak berpengaruh terhadap kondisi financial distress. Hal ini berarti bahwa apabila nilai arus kas operasi yang tinggi dapat dikatakan bahwa penerimaan dari hasil penjualan lebih besar dari beban operasi yang dikeluarkan. Maka akan menunjukan perusahaan yang memiliki nilai arus kas operasional positif tidak akan mengalami kondisi financial distress.

\section{Kesimpulan Dan Saran}

Hasil penelitian yang telah dilakukan oleh penulis pada perusahaan manufaktur yang terdaftar di Bursa Efek Indonesia tahun 2016-2020 mengenai pengaruh likuiditas, profitabilitas, leverage, dan arus kas terhadap kondisi financial distress memperoleh hasil yang berbeda-beda setiap variabel independen terhadap dependen. Penelitian yang dilakukan dengan menggunakan analisis regresi logistis ini diperoleh kesimpulan sebagai berikut:

1. Hasil penelitian ini menunjukan likuiditas tidak berpengaruh terhadap kondisi financial distress. Artinya bahwa apabila perusahaan mampu membayar hutangnya dengan baik dan tepat waktu, maka kemungkinan besar perusahaan tidak akan mengalami kondisi financial distress.

2. Hasil penelitian ini menunjukan bahwa profitabilitas tidak berpengaruh terhadap financial distress. Artinya adalah besar atau kecilnya nilai profit tidak memiliki pengaruh terhadap perusahaan, sehingga terhindar dari kondisi financial distress.

3. Hasil penelitian ini juga menunjukan bahwa financial leverage berpengaruh positif terhadap kondisi financial distress. Artinya adalah jika perusahaan yang memiliki hutang semakin tinggi dan tidak diikuti dengan hasil penjualan yang tinggi, maka dapat memungkinkan kegagalan dalam membayar hutang yang dapat menyebabkan perusahaan dalam kondisi financial distress.

4. Hasil penelitian ini menunjukan bahwa arus kas tidak berpengaruh terhadap kondisi financial distress. Hal ini berarti bahwa apabila perusahaan memiliki nilai arus kas operasional yang baik, maka tidak akan mengalami kondisi financial distress.

\section{Saran untuk Peneliti Selanjutnya}

Berdasarkan hasil penelitian dan kesimpulan yang diuraikan diatas, maka dapat diberikan saran untuk peneliti selanjutnya yaitu diharapkan peneliti menggunakan sampel dari berbagai objek peusahaan lainnya seperti perusahaan real estate, food and beverage dan LQ 45. Selain itu bagi investor maupun calon investor sebaiknya harus lebih selektif dalam memilih perusahaan yang akan dituju untuk berinvestasi dengan melihat laporan keuangannya. Sedangkan bagi perusahaan sebaiknya lebih meningkatkan kinerja 


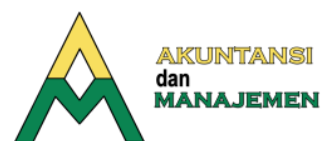

perusahaan dan pengelolaan manajemen yang baik sehingga dapat menarik perhatian investor dalam hal citra baik bagi masyarakat.

\section{Referensi}

[1] Almilia, LS. 2016. Prediksi Kondisi Financial Distress Perusahaan Go Public Dengan Menggunakan Analisis Multinominal Logit. Jurnal Ekonomi dan Bisnis. Vol. 7 No. 1.

[2] Altman, E.I., 1968. Financial Ratio, Discriminant Analysis, and the Prediction of Corporat Bankruptcy. The Journal of Finance, September(25).

[3] Arini, Diah. 2020. Analisis Rasio Keuangan Untuk Memprediksi Kondisi Financial Distress Perusahaan Manufaktur Yang Terdaftar Di Bursa Efek Jakarta. Skripsi thesis, Universitas Muhammadiyah Surakarta.

[4] Atmini, S dan A. Wuryan. 2015. Manfaat Laba dan Arus Kas untuk memprediksi Kondisi Financial Distress Pada Perusahaan Textile Mill Products Dan Apparel And Other Textile Products yang terdaftar di Bursa Efek Jakarta Makalah yang disampaikan pada Simposium Nasional Akuntansi VIII. Solo, 15-16 September.

[5] Boediono. 2015. Tempo.co Jakarta. Diakses pada tanggal 20 November 2015 Pukul 15:00

dengan Menggunakan Analisis Multinomial Logit. Jurnal Ekonomi dan Bisnis. Vol. XII, No. 1.

[6] Foster, G. 1986. Financial Statement Analysis. New Jersey: Prentice Hall, Englewood Cliffs. Gailego, Gomes dan Yanes. 1997. Financial Distress and Corporate Governance: An Empirical Analysis. MCB University Press 1472-0701. Hal. 1523.

[7] Ghozali, Imam. 2002, Multivariate dengan Program SPSS, Badan Penerbit Universitas Diponegoro, Semarang Gujarati, Damodar. 2003. Ekonometrika Dasar. Terjemahan Sumarno Zain. Jakarta: PT. Gelora Aksara Pratama Harahap,

[8] Luciana S. 2016. Prediksi Kondisi Financial Distress Perusahaan Go-Public

[9] Luciana S dan Meliza Silvy. 2013. Analisis Faktor-Faktor yang Mempengaruhi Status Perusahaan Pasca IPO dengan Analisis Multinomial Logit.Jurnal Ekonomi dan Bisnis. Vol. 18, No. 4.

[10] Sofyan Syafri. 2017. Teori Akuntansi. PT. Raja Grafindo Persada: Jakarta. Hery. 2009. Teori Akuntansi. Kencana: Jakarta.

[11] Sugiyono. 2008. Metode Penelitian Bisnis. Edisi Kesebelas. Bandung: Alfabeta 